\title{
Economic grievances and political protest
}

\author{
THOMAS KURER, ${ }^{1}$ SILJA HÄUSERMANN,${ }^{2}$ BRUNO WÜEST ${ }^{2}$ \\ \& MATTHIAS ENGGIST ${ }^{1}$ \\ ${ }^{1}$ Harvard University, USA $;{ }^{2}$ University of Zurich, Switzerland
}

\begin{abstract}
How do economic grievances affect citizens' inclination to protest? Given rising levels of inequality and widespread economic hardship in the aftermath of the Great Recession, this question is crucial for political science: if adverse economic conditions depress citizens' engagement, as many contributions have argued, then the economic crisis may well feed into a crisis of democracy. However, the existing research on the link between economic grievances and political participation remains empirically inconclusive. It is argued in this article that this is due to two distinct shortcomings, which are effectively addressed by combining the strengths of political economy and social movement theories. Based on ESS and EU-SILC data from 2006-2012, as well as newly collected data on political protest in 28 European countries, a novel, more fine-grained conceptualisation of objective economic grievances considerably improves our understanding of the direct link between economic grievances and protest behaviour. While structural economic disadvantage (i.e., the level of grievances) unambiguously de-mobilises individuals, the deterioration of economic prospects (i.e., a change in grievances) instead increases political activity. Revealing these two countervailing effects provides an important clarification that helps reconcile many seemingly conflicting findings in the existing literature. Second, the article shows that the level of political mobilisation substantially moderates this direct link between individual hardship and political activity. In a strongly mobilised environment, even structural economic disadvantage is no longer an impediment to political participation. There is a strong political message in this interacting factor: if the presence of organised and visible political action is a decisive signal for citizens that conditions the micro-level link between economic grievances and protest, then democracy itself - that is, organised collective action - can help sustain political equality and prevent the vicious circle of democratic erosion.
\end{abstract}

Keywords: protest; participation; economic grievances; deprivation; political mobilisation

\section{Introduction}

The study of economic hardship and its unequal distribution in the societies of the OECD world has increased massively over the past decade in economics, sociology and political science. The main driver of this renewed scholarly interest in the determinants and consequences of inequality is substantive: after half a century of increasing equality, the 'great U-turn' (Harrison \& Bluestone 1988) has reversed the secular trend of declining inequality in most highly developed countries from the 1970s onwards (Alderson \& Nielsen 2002). Today, economic inequality - that is, the unequal distribution of economic resources - is on the rise with regard to income (OECD 2008, 2011; Smeeding 2005), wealth (Piketty 2014) and economic risks more generally (Emmenegger et al. 2012; Hacker et al. 2013). The

Correction added on 26 June 2019, after initial online publication. A duplicate of this article was published under the DOI 10.1111/1475-6765.12311. This duplicate has now been deleted and its DOI redirected to this version of the article. 
most recent economic turmoil - the Great Recession that has shaken the OECD from 2008 onwards - has further accelerated these trends and amplified inequalities even more.

Political scientists are right to take a keen interest in this development, since the possible implications of inequality for the functioning of politics and for the quality of democracy are manifold and serious. Despite the importance of this relationship, however, we still do not fully understand how individual hardship - economic grievances - and its unequal distribution in societies - economic inequality - relates to citizens' political behaviour in democracies. The relevant studies theorise and empirically study both demobilising and mobilising effects.

On the one hand, blatant economic inequality may repel and demobilise citizens, especially the weakest among them (Solt 2008), jeopardise political responsiveness and thereby undermine the very foundations of democracy (Dahl 1998). In this respect, eminent scholars such as Offe (2013), Mair $(2006,2013)$ as well as Streeck and Schäfer (2013) have powerfully argued that when citizens experience economic strain and see politicians as unresponsive to their grievances, they may be alienated not only from the current government but from democracy itself. What is more, political alienation of the disadvantaged might spur a vicious cycle of democratic erosion (Bartels 2008), with unequal turnout being mirrored in unequal responsiveness (Griffin \& Newman 2005), which, in turn, produces policies that are detrimental to the disadvantaged and thereby amplify economic inequality. In the end, this self-reinforcing process further depresses participation among the less well-off.

On the other hand, democracy is the one political system that inherently provides citizens with the political and civil rights to mobilise against rising inequality, and to protest their grievances. Democracy provides people with means to voice their disagreements, organise collectively and overturn elites democratically, which is why economic inequality may also stimulate democratic engagement (e.g., Gurr 1970; Brady 2004; Oliver 2001). The widespread protest activity across Europe during the most recent economic crisis has been interpreted in that sense, and it triggered a new wave of research in the tradition of grievance theory (Bernburg 2015; Grasso \& Giugni 2016; Kern et al. 2015; Rüdig \& Karyotis 2014).

Hence, the literature diverges both in the theoretical expectations and empirical findings. In this article, we aim to explain - and to some extent reconcile - some of the contradictory findings by bridging two strands of research that have all too often been treated in isolation: the social movement and the political economy literature. Political economy pays attention to actors' material interest and thus helps to counter the 'strange disappearance of capitalism in social movement studies' (Hetland \& Goodwin 2013), which is especially peculiar in the light of widespread anti-austerity protests around the globe (Della Porta 2015; see also Stanley \& Goodwin 2013). The burgeoning literature that studies protest activity from a political economy angle, in turn, has disregarded a decade-long insight at the heart of the social movement literature - namely that contextual 'opportunity structures' critically moderate the relationship between material conditions and individual inclination to protest. By combining the strengths of both literatures, we are able to explain some of the contradictions in previous research and thereby contribute to a better understanding of the link between economic grievances and protest activity.

The political reactions of citizens experiencing the disadvantages of increasing material disparities are at the heart of the debate about the normative and democratic 
implications of inequality. Accordingly, we focus on the impact of individual economic grievances on political activity. We contend that the divergences in existing studies are due to two distinct shortcomings, which can be effectively addressed by combining the strengths of political economy and social movement theories. Our first concern is the conceptualisation of the central explanatory variable, economic grievances. Especially in the social movement literature, grievances appear as a diversely theorised and measured concept. We demonstrate that a clear-cut differentiation between the level of and change in grievances is crucial for a more thorough understanding of the direct relationship between economic hardship and political participation. The second part of the argument concerns context factors that mediate the direct link between economic hardship and participation. Political economy approaches to political participation have been surprisingly oblivious to such moderation, which is puzzling in the light of the eminently important role this factor has played in social movement theories for a long time (e.g., Kitschelt 1986). Recently, Grasso and Giugni (2016) have rightly pointed to this all-too often disregarded interaction effect and introduced the institutional context and the economic environment as mediating factors in the analysis. Beyond institutions and structural conditions, however, we argue that a more actor-centred conceptualisation, considering the role of political mobilisation (i.e., the presence of visible, organised protest), is equally relevant and captures the underlying mechanism that many of the context-arguments rely on (in particular, the 'signaling' effect of opportunities) more precisely (see Kriesi 2004). Citizens need signals in order to be both able and willing to voice their grievances (Granovetter 1978; Tarrow 1994). This idea is also nicely reflected in Verba et al.'s (1995: 269) three famous factors to explain why citizens refrain from political engagement: because they can't, because they don't want or because nobody asked. The third reason clearly hints at an interaction between socioeconomic status and the mobilising context effects. Neglecting this interaction between the political context and economic grievances may leave us not only with an incompletely specified model of political behaviour, it may also suggest an all too fatalistic picture of democracy in times of increasing inequality.

Our theoretical conceptualisation, measurement and empirical analysis of (1) economic micro-level determinants, (2) facilitating contextual factors and (3) the interaction between them yield two important findings on the relationship between individual hardship and political reaction. First, we show that our new, more fine-grained conceptualisation of objective economic grievances considerably improves our understanding of the direct effect of economic grievances on protest behaviour. While structural economic disadvantage (i.e., the level of grievances) unambiguously de-mobilises individuals, the deterioration of economic prospects (i.e., a negative change in economic grievances) instead increases political activity. This direct comparison of the two countervailing effects provides an important clarification that helps reconcile many seemingly conflicting findings in the existing literature, and to reassess the value of objective measures of economic grievances as compared to subjective measures, which have become more widespread in social movement research. Second, we provide robust empirical evidence for our conjecture that the level of political mobilisation substantially moderates this link between individual hardship and political activity. In a strongly mobilised environment, even structural economic disadvantage is no longer an impediment to political participation. We contend that there is a strong political message in this interacting factor: if the presence of organised and visible 
political action is a decisive signal for citizens and conditions the micro-level link between economic grievances and protest, then democracy itself (i.e., organised collective action) can help sustain political equality and prevent the vicious circle of democratic erosion.

\section{Economic grievances and participation in the literature}

Research about the relationship between economic adversity and political engagement exists with a focus on the micro- as well as the macro-level. The first is concerned with individual socioeconomic status related to (shocks in) resources such as income or unemployment (e.g., Rosenstone 1982; Verba \& Nie 1972), whereas the latter deals with the aggregation and often unequal distribution of those resources (e.g., Blais \& Dobrzynska 1998; Solt 2008). Although we focus on the micro-level in the empirical analysis, the literature concerned with the distribution of grievances helps us to connect the individuallevel findings to their fundamental political implications for society as a whole. Economic inequality is always rooted in the differential distribution of economic hardship, so the two debates are inevitably coupled.

Interestingly, both the micro- and the macro-level research strands are characterised by the same division into two competing perspectives that imply fundamentally different theoretical expectations. On the one hand, the 'mobilisation hypothesis' (Schlozman \& Verba 1979) or 'grievance theory' (Kern et al. 2015) expects disadvantaged voters to blame the government for their situation and actively express their dissatisfaction both through the ballot box and out on the streets. Along similar lines, Solt (2008) tackles the issue from a distributional perspective and hypothesises that economic inequality may produce clear-cut differences in preferences between the rich and the poor, which fuels the debate about appropriate policy decisions and raises the stakes of elections. The logic behind this 'conflict theory' has implications for our micro-level relationship between economic hardship and political activity: growing economic grievances incentivise participation and increase turnout among the disadvantaged. The findings of several studies support these hypotheses on the basis of cross-national or cross-regional evidence (e.g., Brady 2004; Oliver 2001).

The 'withdrawal hypothesis' (Rosenstone 1982), on the other hand, makes exactly the opposite claim: economic grievances demobilise participation. Individuals confronted with (increasing) economic strain may be strongly preoccupied with making ends meet and hence lack the capacity to engage in politics (Rosenstone 1982). Again, Solt (2008) tests a similar hypothesis based on the aggregate distribution of grievances in society: according to relative power theory, the economically disadvantaged will refrain from political participation due to the lessons learnt from the existing imbalance in political influence and power. Economic inequality equips the affluent with disproportionate capabilities to influence politics, while the voices of poorer individuals are consistently ignored. Repeated political decisions to the detriment of the less well-off eventually make disadvantaged individuals realise that their attitudes are unlikely to prevail in the political process. Consequently, they may avoid wasting time with futile political participation and decide to abstain.

Diverging evidence with respect to the two competing hypotheses is, however, not the only limitation of the literature on inequality and political participation. Most of the existing research also adopts a rather narrow focus on conventional political participation 
and is primarily concerned with the effect of economic grievances on the propensity to vote. However, such a focus on national elections and electoral behaviour might actually be problematic when assessing the political consequences of economic hardship. First, electoral politics and the economy follow different temporal patterns. At the time of experiencing economic adversity, a reaction via elections might simply not be at citizens' disposal. Particularly in the context of the widespread harm caused by the recent financial crisis, a strong and sudden macroeconomic shock, citizens are likely to look for immediate opportunities to express their grievances rather than waiting for the next election to punish governments at the ballot box (Kriesi 2014). Second, even if elections happen to be scheduled in the midst of economic turmoil, the opportunities to express economic grievances still remain strongly constrained by political supply-side factors: voters depend on the existing parties, or the candidates running for election, and might not find a suitable channel to satisfactorily express their dissatisfaction (e.g., Häusermann et al. 2018). This is why in this article we focus on unconventional political participation - that is, participation in demonstrations, supporting boycotts or signing petitions. These are means of political engagement that are available at any time for anyone, whenever deemed necessary and effective.

And yet, studies linking economic grievances to political protest behaviour also provide us with conflicting evidence. The idea that social unrest evolves as a reaction to injustice and widespread deprivation figured prominently in traditional Marxian theories on protest and revolution. In the 1940s and 1950s, the theory has been refined insofar as the focus shifted from deprivation in absolute terms to relative deprivation - that is, unmet expectations (see, e.g., Geschwender 1964; Gurr 1970; Runciman 1966). However, the relative deprivation approach largely failed to prove its explanatory power in empirical work, as there did not seem to be a direct link between (relative) deprivation and protest behavior, and increasingly fell out of fashion (Gurney \& Tierney 1982). During the recent economic crisis, however, this link has again gained momentum: the simultaneous occurrence of a widespread increase in economic hardship and the impressive surge in unconventional political mobilisation renewed the scholarly interest in grievance theory and triggered new empirical evaluation on economic determinants of political protest (Bernburg 2015; Della Porta 2015; Giugni \& Grasso 2015; Grasso \& Giugni 2016; Kern et al. 2015; Rüdig \& Karyotis 2014; Solt 2015). Nevertheless, this more recent empirical work does not conclusively answer whether economic hardship mobilises or de-mobilises citizens: single-country studies as well as comparative evaluations come to diverging conclusions regarding the impact of grievances on protest activity (see, e.g., Bernburg (2015) on Iceland; Rüdig \& Karyotis (2014) on Greece; or Solt (2015) for a comparative study).

How can we make sense of the link between the unequal distribution of economic risk and participation? We argue that the current literature suffers from two shortcomings, for which we offer conceptual (and empirical) responses in this article. On the one hand, the concept of 'economic grievances' deserves more careful consideration, in particular the differentiation between level of and change in hardship. Existing studies have examined the political reactions to either economic grievances compared to others (Kern et al 2015; Solt 2015) or economic grievances compared to people's previous experiences (Bernburg 2015; Grasso \& Giugni 2016; Rüdig \& Karyotis 2014) but never contrasted both forms of economic hardship directly. Since the behavioural implications of those two distinct 
experiences are very different, as we argue and demonstrate below, this implicit and partial examination of what grievances mean has contributed to the conflicting evidence that characterises the existing body of work. On the other hand, political economy research in particular has paid too little attention to the effect of context. Despite the prominence of this argument in the social movement literature (e.g., Grasso \& Giugni 2016), the conditioning role of mobilisation and opportunity structures is oftentimes neither theorised nor analysed empirically. Hence, we build on a key finding of the social movement literature - namely the fact that context (i.e., mobilisation and opportunity) matters. People must be mobilised and collective actors have to politicise grievances.

\section{Grievances as driver of protest and political mobilisation as moderator}

Our argument starts from the observation that the existing literature has devoted too little attention to the precise conceptualisation of (objective) economic grievances. When reviewing the relevant literature, at least two conceptualisations of grievances as drivers of protest can be identified. A first strand is concerned with grievances as a relative concept that is, as the experience of disproportionate economic hardship compared to other parts of society (e.g., Kern et al. 2015; Solt 2015). In the literature on conflict studies, this concept has been coined 'horizontal inequality' and has proved its explanatory power regarding civil war and violent upheavals (Cederman et al. 2011; Ostby 2008). In the comparative political economy literature, similar conceptualisations of relative economic hardship have been applied to measuring insecurity and labour market disadvantage (Rehm 2009, 2011; Schwander \& Häusermann 2013). A second strand of literature also emphasises a relative aspect of grievances, but focuses on the importance of a temporal dimension of comparison: the importance of a deterioration in the economic circumstances. In this view, the grievances of an individual refer to his or her economic hardship relative to what the individual experienced in the past. This is at the heart of traditional relative deprivation theory (Runciman 1966; Gurr 1970) and has found application in recent examinations of protest behaviour during the Great Recession (Rüdig \& Karyotis 2014; Bernburg 2015; Grasso \& Giugni 2016).

Both measures involve a relative component, either a static-societal or an individualdynamic one. However, to the best of our knowledge, existing work has never examined these two distinct notions of grievances, based on either a social or a historical/intertemporal reference point (see Simon 1939), vis-à-vis each other, although distinct behavioural implications can be expected. Social reference points highlight relative differences in economic hardship between different subgroups of society. The general pattern of vertical, longstanding and systematic discrepancies in resource endowment between individuals or groups remains relatively stable over time. In terms of economic grievances, such structural disadvantage is closely related to the arguments of the socioeconomic model, an empirically powerful approach claiming that lower relative socioeconomic status results in lower political participation (Verba \& Nie 1972; Milbrath \& Goel 1977; Wolfinger \& Rosenstone 1980). Intertemporal comparisons, on the other hand, deliver a very different kind of reference point. Deprivation over time can happen on any level of absolute economic hardship, is much more volatile and potentially affects a much broader and more diverse subset of society. Its correlation with socioeconomic status may therefore be weak. Hence, 
the experience of deteriorating economic conditions over time is not so strongly related to resources, the first pillar of political participation as famously proposed by Verba et al. (1995), but rather to the second pillar: motivation or psychological engagement. In contrast to structural and relatively stable differences in the vertical distribution of resources, deprivation over time is expected to produce a kind of dissatisfaction, frustration or even anger beneficial to political activity (Barnes et al. 1979). This difference is likely to be highly relevant empirically. ${ }^{1}$ However, when measuring economic grievances, researchers are oftentimes constrained by the availability of specific survey items, which do not allow for a careful conceptualisation of distinct forms of grievances based on different dimensions of social or intertemporal comparison.

The second part of our argument emphasises the idea that the relationship between individual-level experiences of economic hardship and participation in protest activities depends on the presence or absence of a crucial context condition: political mobilisation. By 'political mobilisation', we mean publicly visible collective action, usually organised by protest entrepreneurs such as trade unions, political parties or civil society groups. We expect that political mobilisation conditions the link between economic grievances and protest.

The literature on individual economic determinants of protest behaviour and the literature on the context conditions of non-conventional political action have lived rather separate lives for a long time. Social movement studies have traditionally conceptualised individual protest reactions as a function of the political environment - that is, the political opportunity structure (Arzheimer 2009; Della Porta 2008; Eisinger 1973; Kitschelt 1986; Kriesi 1989; Kriesi et al. 1992). Mostly, this political opportunity structure is defined as an exogenous source of mobilisation including the behaviour of allies, adversaries and the public, the permeability of the political system as well as societal, economic and cultural context conditions (Koopmans 1999). As for the literature on individual economic determinants of protests, Grasso and Giugni (2016) only recently suggested that micro- and macro-level factors might be interrelated. They provide evidence that 'political opportunities' - that is, the macroeconomic context (the unemployment rate) and certain policies (social policy spending) - strengthen the link between economic grievances and protest participation. Our argument clearly builds on the reasoning by Grasso and Giugni (2016), but we take a substantively different, more actor-centred, view on political context conditions. Economic strain does not in and of itself trigger or mediate protest (Kitschelt 1986: 59). Rather, people's grievances must be politicised. Collective actors - political entrepreneurs - play a crucial role in this process, since they use and provide political opportunities in terms of mobilisation. Insofar, public attention to protest is itself a major source of further political mobilization - an argument that figures prominently in many classic social movement studies (e.g., Della Porta 2014; Granovetter 1978; Tarrow 1994).

The moderating role of political mobilisation on individual protest behaviour relies on two mechanisms. The first mechanism, theorised in the social movement literature (Kriesi et al.1995), is concerned with the organisational capacity of social movement entrepreneurs to facilitate the emergence of collective protest. The financial and organisational power and strength of these entrepreneurs varies strongly between different national contexts and helps explain the occurrence of protest activity. Related to this more formal channel, however, we identify a second, equally important mechanism at the individual level: increased visibility of ongoing protest sends signals to individuals and encourages them 
to participate in protest activities and publicly voice their dissatisfaction. For our research question, this second micro-level mechanism is crucial, as it links individual-level grievances and individual-level protest behaviour.

The underlying rationale behind the second mechanism is based on the fact that an increase in publicly visible collective protest will encourage and incentivise protest behaviour among citizens who experience economic grievances, but who have not yet been engaged in protest activities themselves. At the level of an individual, mobilisation occurs through two different channels: a demonstration effect and an attribution effect. The former refers to 'threshold models' of political protest (Granovetter 1978; Kuran 1991), meaning that citizens' beliefs in the value of participating in protests may change when the intensity of existing protest passes a certain threshold. This threshold for mobilisation is particularly important in contexts where protesting is very costly (e.g., in terms of (violent) repression), but it is likely to matter even without repression, as existing protest conveys informational cues to citizens about the legitimacy and value of voicing their discontent. Citizens see that many other fellow citizens believe in the fact that their protests are valuable and potentially effective. In addition, ongoing political protest events obviously reduce the costs citizens incur from protesting, since they can join existing events rather than having to organise collectively from the start. Protest can then spread through bandwagon effects (e.g., Tarrow 1994) and informational cascades (Lohman 1994), meaning that media coverage of the protests multiplies the signals received by the population. The more information media convey about protests, the more potential adopters are exposed to information whether collective actions are considered legitimate, reasonable and realistic by society at large (Braun \& Koopmans 2009; McCammon et al. 2007). The second channel through which citizens may be mobilised to protest has less to do with informational cues emanating from existing protest but with the attribution of grievances. Particularly in the area of economic grievances (i.e., the experience of deprivation such as unemployment or income loss), the reaction of an individual to this experience depends on whether a person attributes the grievance to her own fault or whether she blames outside factors for this grievance. For example, the effect of individual unemployment on participation in elections crucially depends on the current unemployment rate: in a context of rising unemployment rates, joblessness is increasingly conceived as a societal problem for which the government should provide a remedy and consequently rather mobilises than de-mobilises unemployed voters (Incantalupo 2011; Grasso \& Giugni (2016) theorise a similar mechanism). In a similar vein, Arzheimer (2009) points to the importance of 'shared sufferings' as a precondition for political protest against economic grievances. By seeing more and more other citizens who have experienced similar deprivation blaming the elites and asking for protective political actions, we would expect citizens to be encouraged to participate in protests themselves, as they see their frustrations shared and legitimised.

\section{Data, measures, method}

We draw on three different data sources in order to compile a dataset that provides an accurate measure for each of the three core concepts (protest, grievances and mobilisation) of this article. The first source of our analysis is the European Social Survey (ESS), a comparative survey that contains detailed questions about individual protest behaviour. 
Respondents are asked whether during the year preceding the survey they took part in a demonstration, signed a petition, wore a protest badge or boycotted certain products. For the dependent variable, we created a dummy variable coded as 1 if a respondent answered one of these four questions affirmatively. ${ }^{2}$

For our core independent variables, we draw on EU-SILC data and suggest unemployment risk as a valid indicator of individual-level grievance in times of economic crisis. We focus on unemployment because losing a job is a clearly defined form of objective economic hardship that is known in every country of our sample and very close to the theoretical mechanisms proposed above. We focus on risk (rather than actual unemployment) because we are not primarily interested in a snapshot of a respondent's economic situation but in a more gradual manifestation of economic hardship. While employment status may fluctuate strongly across short time-spans, unemployment risk reflects gradual and structural economic threat and hardship more validly. This is why risk-based conceptualisations of economic hardship have become mainstream measures of economic hardship in comparative political economy, predicting political preferences and behaviour (Rehm 2009, 2011; Rehm et al. 2012; Schwander \& Häusermann 2013; Häusermann et al. 2015; Rovny \& Rovny 2017). In line with these contributions, we conceptualise risk as the prevalence of a specific form of economic vulnerability, unemployment in our case, within an occupational group. ${ }^{3}$ To bring in the two relevant dimensions of comparison developed above, we relate these group-specific unemployment rates to (a) the average unemployment rate in the country (in order to capture the societal reference point) and (b) to the group-specific unemployment rate in the previous year (in order to capture the temporal reference point). While the first approach to some extent approximates socioeconomic status (i.e., a presumably quite stable vertical stratification between socioeconomic groups), the second approach dynamically captures changes in economic hardship within each class. We call the first measure of grievances 'relative status' in order to highlight the status-based nature the concept and the comparison with the societal average. The second measure we call 'deprivation', which emphasises the temporal aspect inherent to this concept.

$$
\begin{aligned}
& \text { relative status }=\text { grievance }_{i, t}-\text { grievance }_{j, t} \\
& \text { deprivation }_{=\text {grievance }_{i, t}}-\text { grievance }_{i, t-1}
\end{aligned}
$$

where $\mathrm{i}$ denotes the occupational group and $\mathrm{j}$ the entire country. Take, for example, a production worker in the midst of the Spanish unemployment crisis in 2012. According to EU-SILC, the unemployment rate within this occupational group at that time was 33.1 per cent, the average unemployment rate in Spain was at 21.1 per cent. This yields a relative status of 12.0. As unemployment among production workers was at 26.6 per cent in the previous year, deprivation amounts to 6.4 in 2012. The values of the two grievance measures reflect Spanish production workers' double disadvantage in both societal and temporal terms. Much in contrast, unemployment among Spanish large employers and liberal professionals was at a comparatively low 9.3 per cent in 2012. A relative status of -11.8 (9.3 per cent minus 21.1 per cent) reflects the comparatively comfortable position of this occupational group. However, even this privileged occupational group has not been spared by the surge of unemployment during the Great Recession and a deprivation value 
of 3.0 captures the group-specific increase in unemployment from 6.3 per cent in 2011 to 9.3 per cent in 2012. Even highly skilled and specialised occupational groups thus experienced a significant increase in economic grievances, which might trigger political action - despite relatively low vulnerability compared to the rest of the country. We calculate economic grievances based on the European Union Statistics on Income and Living Conditions (EU-SILC). In the Online Appendix, we provide detailed descriptive statistics on the values of the two resulting measures of economic grievances for each country and year in our sample.

It has to be noted that such a conceptualisation of grievances differs from the standard approaches in both social movement and political economy research. In the social movement literature, grievances are usually understood as subjective perceptions of hardship such as fear of unemployment (see, e.g., Galais \& Lorenzini 2017), whereas contributions from political economy often rely on objective measures of material conditions, such as employment status. However, a large body of research on the concept of 'relative deprivation' has demonstrated that there is often little relation between such objective material conditions and, for example, satisfaction with one's income (see Pettigrew (2016) for a valuable overview).

Our measure represents a middle ground, as we measure unemployment vulnerability within the respondent's occupational group and contrast this current level with (a) other parts of society and (b) previous levels within the same occupational group. In so doing, we avoid both a too simplistic operationalisation based on objective status, as well as an entirely subjective indicator that entails risks of tautology when it comes to protest behaviour. Insofar, we propose a measure that takes both strands of research seriously. Ultimately, we measure economic grievances on the basis of objective economic data but we focus on experienced hardship relative to social and intertemporal reference points. The underlying theoretical mechanism clearly runs via subjective perceptions of strain.

An observable implication of this micro-level mechanism is that those occupational groups characterised by higher levels of relative status and/or deprivation should have higher levels of subjectively perceived grievances. Indeed, existing research has demonstrated that objectively measured levels of unemployment risk are strongly correlated with individual perceptions of risk exposure (most importantly, Rehm 2016) and we are able to replicate these positive correlations between our measures of grievances and individual's subjective perceptions within the (admittedly limited) possibilities provided by the ESS. Table SI9 in the Online Appendix shows that higher levels of both our measures of economic grievances, relative status and deprivation, are associated with (a) less optimistic feelings about the household's income, (b) higher levels of subjective dissatisfaction with how the national economy is going, which translates into politicized grievances such as (c) higher levels of subjective dissatisfaction with the government. Moreover, very much in line with our expectation of distinct behavioural reactions, the regressions confirm that relative status is more strongly related to lower socioeconomic perceptions (feeling about household income), whereas the intertemporal deprivation variable has stronger effects on subjective dissatisfaction with the economy and the government. We interpret this difference in the strength of the association as evidence for the theoretical mechanisms we have developed above: while relative status is tightly linked to socioeconomic resources and thus demobilises 
protest, deprivation is more closely connected to frustration or anger and dissatisfaction, which is why we expect it to have a mobilising effect.

Finally, for our moderator variable, political mobilisation, we need a measure that captures the visibility and activity of protest movements. Since we focus on the signaling effects of political mobilisation, visibility is key. This is why we rely on data that records protest reports in the media. We think that aggregated and dynamic media data on protest activity is ideal to capture the signaling effects, which form the core of our theoretical argument. More traditional and static indicators of political mobilisation (such as trade union density) might be appropriate to measure the financial and organisational capacity of movement entrepreneurs, but this is not what we are primarily interested in here (see the discussion of the key theoretical mechanisms above). Instead, we rely on original protest event data from 28 European countries in the years 2000-2015 (see Lorenzini et al. (2016) for details on the data: the data was collected by two research teams at the University of Zurich and the European University Institute in Florence in the years 2014-2015). In total, we have information about roughly 32,000 events that were reported in ten international news agencies over the time of observation. Availability of EU-SILC data narrows the time-span under examination to the years 2005-2014, which reduces the final number of protest events that are used in the analysis below to about 20,000 (see Table A1 in the Appendix for details). ${ }^{4}$

In order to merge this protest data with the micro-level data from ESS and EU-SILC, we add up the monthly number of protest events covered by the media within the one year preceding the ESS interviews ( $\mathrm{t}-1$ to $\mathrm{t} 0$ ) to match the wording of the ESS questionnaire, which asks respondents whether they took part in any form of non-electoral political participation during the last 12 months. ${ }^{5}$ For our moderator variable, we are particularly interested in the change of number of protests, since the different levels of protest activity are relatively stable between countries. Therefore, we also added up the number of protests in the period from t- 2 to t- 1 ( 24 to 13 months before the ESS survey) in order to calculate the change in the absolute number of protests in each country during the relevant period in which respondents' protest activity was asked for ( $\mathrm{t}-\mathrm{t}$ to $\mathrm{t} 0$ ). This is a more valid indicator of a vibrant and mobilising atmosphere of collective action and engagement than the mere level of activity, because people in countries with an active protest culture are quite likely to get used to a 'baseline level' of non-electoral opposition. ${ }^{6}$

It is important to note here that our moderator variable (extracted from newswire articles on protest events) and our dependent variable (self-reported individual participation in protest activity) capture two distinct concepts. Our indicator of collective mobilisation is based on media reporting and captures the number of events covered, irrespective of their number of participants. It measures the intensity of media coverage on protests and therefore the extent to which opposition and resistance are visible at the aggregate level. Media reports on protest convey the public mood and have an important communication function insofar as they signal to (potential) protesters the degree to which others already have taken action. Our dependent variable, by contrast, measures individual behavior that is, a decision to voice discontent or remain silent. The moderator and the dependent variable are thus conceptually and empirically distinct, because the moderator variable is based on the number of reported protest events and not on the number of protesting individuals. Indeed, there is virtually no correlation between media reporting on protest 
and individual participation in protest. ${ }^{7}$ Moderator and dependent variable coincide only if every respondent staged his or her own protest event, which is spectacular enough to be covered by the media.

We have combined several waves of the ESS (ESS3-6 covering the period 2006-2012) in order to capture the entire time-span from before the outbreak of the financial crisis onwards for 28 European countries. ${ }^{8}$ We add the data from EU-SILC by merging on Oesch's (2006) eight-class schema for each of the years in the dataset: 2006, 2008, 2010 and 2012. Similarly, we add the data on protest mobilisation from our own data collection. This results in a large dataset of more than 200,000 observations. Due to the nested structure of the data (individuals in countries in different years) and the binary dependent variable, we run hierarchical logistic mixed-effects models. ${ }^{9}$ We refrain from analysing the data as a three-level structure as suggested by Schmidt-Catran and Fairbrother (2016) because of the specific construction of our measures of economic grievances. While the variable is technically situated at the lowest level, it entails information from the country dimension of the cross-classification at a specific time point. This is not a real problem when we only include the cross-classification in the data structure. When we also seek to estimate effects at the country-year level, however, then we create a collinearity problem, which results in unstable estimates. ${ }^{10}$

In order to better isolate the (conditional) effect of economic grievances on individual protest activity, we control for potential confounders on both levels of analysis. On the microlevel, we control for well-known alternative individual determinants of protest participation: education, gender, age, employment status, union/organisational membership and being in a relationship (see, e.g., Solt 2015). We do not control for political values and political efficacy, which are sometimes included in grievance studies of protest behaviour, because our operationalisation of the key independent variables (grievances) is based on objective unemployment rates per occupational group. Consequently, political values and efficacy are part of the causal mechanism rather than confounders. On the macro-level, we add a variable measuring trade union density per country and year in order to separate the impact of financial and organisational capacity of protest movements from our signaling mechanism. Furthermore, we control for the party in government as well as for the official unemployment rate at the time of the survey, which capture the influence of the general political and economic context on protest behaviour (Kriesi et al. 1995). Table A2 in the Appendix summarises descriptive statistics. Further country- and year-specific descriptive information on all variables is provided in the Online Appendix.

\section{Analysis and results}

The first part of this article's empirical section is concerned with the direct relationship between economic grievances and political participation. As has been outlined above, the literature is characterised by fundamental disagreement even regarding the direction of this effect. Does economic hardship mobilise dissatisfied citizens to protest their adverse circumstances or does it lead to a focus on more existential threats reducing their 'capacity to attend to politics' (Rosenstone 1982)? Table 1 provides evidence against any univocal answer to this question: it highlights the importance of conceptualisation and the differences resulting from distinct points of comparison (social versus intertemporal). 
Table 1. Economic grievances and protest: Direct effects

\begin{tabular}{|c|c|c|c|c|c|}
\hline & Model 1 & Model 2 & Model 3 & Model 4 & Model 5 \\
\hline Relative status & & $\begin{array}{l}-2.941^{\text {*a**** }} \\
(0.175)\end{array}$ & & $\begin{array}{l}-3.013^{\text {*3*t }} \\
(0.196)\end{array}$ & \\
\hline Deprivation & & & $\begin{array}{l}2.153^{20.60} \\
(0.503)\end{array}$ & & $\begin{array}{l}2.190^{* * * \hbar} \\
(0.599)\end{array}$ \\
\hline Age & $\begin{array}{l}-0.004^{* * * *} \\
(0.000)\end{array}$ & $\begin{array}{l}-0.004^{* * *} \\
(0.001)\end{array}$ & $\begin{array}{l}-0.003^{* * *} \\
(0.001)\end{array}$ & $\begin{array}{l}-0.004^{* * * *} \\
(0.001)\end{array}$ & $\begin{array}{l}-0.003^{* * *} \\
(0.001)\end{array}$ \\
\hline Female & $\begin{array}{l}0.149^{2.60} \\
(0.011)\end{array}$ & $\begin{array}{l}0.142^{\text {whosk }} \\
(0.012)\end{array}$ & 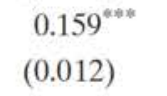 & $\begin{array}{l}0.142^{\text {*1***t|}} \\
(0.013)\end{array}$ & $\begin{array}{l}0.161^{* * * *} \\
(0.013)\end{array}$ \\
\hline Education & $\begin{array}{l}0.285^{* * *} \\
(0.005)\end{array}$ & $\begin{array}{l}0.251^{* 6 *} \\
(0.005)\end{array}$ & $\begin{array}{l}0.278^{* * * *} \\
(0.005)\end{array}$ & $\begin{array}{l}0.253^{* * 4} \\
(0.005)\end{array}$ & $\begin{array}{l}0.280^{\text {*t**1*}} \\
(0.005)\end{array}$ \\
\hline EmpStat.: education & $\begin{array}{l}0.329^{* * * *} \\
(0.024)\end{array}$ & $\begin{array}{l}0.556^{\text {te*k }} \\
(0.030)\end{array}$ & $\begin{array}{l}0.549^{\text {****k }} \\
(0.030)\end{array}$ & $\begin{array}{l}0.580^{\text {s.no }} \\
(0.033)\end{array}$ & $\begin{array}{l}0.572^{\text {**** }} \\
(0.033)\end{array}$ \\
\hline EmpStat.: unemployed & $\begin{array}{c}-0.045 \\
(0.025)\end{array}$ & $\begin{array}{c}0.011 \\
(0.026)\end{array}$ & $\begin{array}{l}-0.031 \\
(0.026)\end{array}$ & $\begin{array}{c}-0.014 \\
(0.029)\end{array}$ & $\begin{array}{l}-0.059^{*} \\
(0.029)\end{array}$ \\
\hline EmpStat.: retired & $\begin{array}{l}-0.214^{* * *} \\
(0.020)\end{array}$ & $\begin{array}{l}-0.212^{\text {*8* }} \\
(0.021)\end{array}$ & $\begin{array}{l}-0.219^{\text {***** }} \\
(0.021)\end{array}$ & $\begin{array}{l}-0.217^{\text {*a* }} \\
(0.023)\end{array}$ & $\begin{array}{l}-0.224^{* * * * k} \\
(0.023)\end{array}$ \\
\hline EmpStat.: housework & $\begin{array}{l}-0.126^{* * * *} \\
(0.023)\end{array}$ & $\begin{array}{c}-0.070^{* 8} \\
(0.024)\end{array}$ & $\begin{array}{l}-0.091^{* * *} \\
(0.024)\end{array}$ & $\begin{array}{l}-0.077^{* \bullet} \\
(0.026)\end{array}$ & $\begin{array}{l}-0.097^{\text {**** }} \\
(0.026)\end{array}$ \\
\hline EmpStat.: other & $\begin{array}{c}0.149^{\circ} \\
(0.049)\end{array}$ & $\begin{array}{c}0.181^{* * t} \\
(0.059)\end{array}$ & $\begin{array}{c}0.181^{* \phi} \\
(0.059)\end{array}$ & $\begin{array}{c}0.147^{*} \\
(0.065)\end{array}$ & $\begin{array}{c}0.147^{*} \\
(0.065)\end{array}$ \\
\hline Partner & $\begin{array}{l}0.067^{* * * *} \\
(0.012)\end{array}$ & $\begin{array}{l}0.042^{* 2 *} \\
(0.012)\end{array}$ & $\begin{array}{l}0.048^{* * * *} \\
(0.013)\end{array}$ & $\begin{array}{c}0.042^{* *} \\
(0.014)\end{array}$ & $\begin{array}{l}0.047^{\text {t**** }} \\
(0.014)\end{array}$ \\
\hline Union member & $\begin{array}{l}0.283^{\text {matik }} \\
(0.015)\end{array}$ & $\begin{array}{l}0.291^{\text {t.8.8. }} \\
(0.016)\end{array}$ & $\begin{array}{l}0.281^{\text {"**** }} \\
(0.016)\end{array}$ & $\begin{array}{l}0.310^{\text {**as }} \\
(0.017)\end{array}$ & 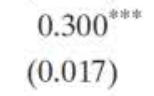 \\
\hline Other association member & $\begin{array}{l}1.293^{* * * *} \\
(0.015)\end{array}$ & $\begin{array}{l}1.255^{\text {senk }} \\
(0.016)\end{array}$ & $\begin{array}{l}1.264^{* * * *} \\
(0.016)\end{array}$ & $\begin{array}{l}1.279^{* * 0} \\
(0.017)\end{array}$ & $\begin{array}{l}1.288^{* n+k} \\
(0.018)\end{array}$ \\
\hline Unemployment rate & & & & $\begin{array}{c}0.087 \\
(0.435)\end{array}$ & $\begin{array}{l}-0.187 \\
(0.472)\end{array}$ \\
\hline Union density & & & & $\begin{array}{c}0.004 \\
(0.005)\end{array}$ & $\begin{array}{c}0.004 \\
(0.005)\end{array}$ \\
\hline GovParty: Dom Right & & & & $\begin{array}{c}-0.107^{* * *} \\
(0.029)\end{array}$ & $\begin{array}{l}-0.098^{\text {E*** }} \\
(0.029)\end{array}$ \\
\hline GovParty: Balance & & & & $\begin{array}{c}-0.113^{2 * 0 *} \\
(0.023)\end{array}$ & $\begin{array}{l}-0.102^{=* 11 *} \\
(0.024)\end{array}$ \\
\hline GovParty: Dom Left & & & & $\begin{array}{l}-0.142^{* * * *} \\
(0.036)\end{array}$ & $\begin{array}{l}-0.141^{\text {**** }} \\
(0.036)\end{array}$ \\
\hline GovParty: Heg Left & & & & $\begin{array}{c}0.122^{2} \\
(0.036)\end{array}$ & $\begin{array}{l}0.125^{* * * *} \\
(0.036)\end{array}$ \\
\hline AIC & 200262.524 & 183386.641 & 179795.487 & 153791.199 & 150170.858 \\
\hline Number of observations & 191,320 & 173,263 & 169,115 & 148,289 & 144,141 \\
\hline Num. groups: cntry & 28 & 28 & 28 & 27 & 27 \\
\hline Num. groups: year & 5 & 5 & 5 & 4 & 4 \\
\hline Var: cntry (Intercept) & 0.621 & 0.622 & 0.612 & 0.562 & 0.540 \\
\hline Var: year (Intercept) & 0.008 & 0.009 & 0.010 & 0.002 & 0.002 \\
\hline
\end{tabular}

Note: *** $\mathrm{p}<0.001 ;{ }^{* *} \mathrm{p}<0.01 ;{ }^{*} \mathrm{p}<0.05$. 
While model 1 only includes covariates on the micro-level, our first measure of economic grievances - relative status - is introduced in model 2. Our static variable of economic grievances, measured as group-specific unemployment rate compared to the average unemployment rate in the country, clearly shows a demobilising effect. Given the similarity between this measure and conventional indicators of socioeconomic status, this might not come as a surprise. The 'resource school' of political participation (e.g., Brady et al. 1995) has long argued that communication and organisational capacities essential to political engagement are closely related to socioeconomic status. This view is corroborated by model 2 , which shows that occupational classes with higher-than-average unemployment risk tend to participate less in non-electoral participation. Model 3, however, adds interesting nuance to this finding. A change in the level of grievances over time - that is, an increase in the group-specific exposure to unemployment - is related to an increase in the probability of political activity. In contrast to the temporally rather stable, status-based measure in model 2 , the deterioration of a person's situation has a mobilising effect. ${ }^{11}$ To understand this link, it is important to notice that the deterioration may happen at different levels of socioeconomic status. The increase of unemployment risk (i.e., the economic deterioration) is a disconcerting experience at any level of relative status. The difference between the demobilising effect of relative status and the mobilising effect of over-time deprivation is an interesting finding, which highlights the importance of conceptualisation and measurement, and quite likely helps explain some of the inconclusive evidence reviewed in the theory section. This finding is robust to the inclusion of additional covariates on the macro-level (models 4 and 5).

Let us now turn to the second empirical question of this article: Does mobilisation condition the relationship between economic grievances and unconventional participation? In Table 2, we add the discussed moderator - mobilisation - to the equation (models 1 and 2) and interact it with our measures of economic grievances (models 3 and 4 ). If the formulated expectation is correct, the model should return positive interaction effects that either reduce negative effects of status-based grievances (societal, horizontal dimension) or reinforce mobilising effects of a worsening of economic circumstances over time (intertemporal dimension). This is exactly what we find. Both interaction terms are positive and statistically highly significant. An increase in mobilisation and opportunity indeed seems to activate citizens confronted with economic hardship.

In order to get a better grasp of absolute levels of (de)mobilisation, Figure 1 plots the logged odds ratio of economic grievances on participation in protests, conditional on the level of mobilisation and opportunity. The left plot shows the logged odds ratio of our first grievance measure - relative status - conditional on the level of political mobilisation. ${ }^{12}$ As we would expect from the results in Table 2, lower relative status generally depresses political activity: the (logged) odds ratio for this variable usually remains in the negative domain below the horizontal zero-line. However, this negative effect is clearly mitigated in a more active protest environment, which provides more opportunities to voice dissatisfaction, and in fact fully disappears in circumstances with an exceptional surge in mobilisation.

The plot on the right hand displays the same conditional logged odds ratio for the case of deprivation. Again, this plot corroborates our findings from Table 2. On average, a deterioration of their situation has a mobilising effect on citizens - and this effect is 
Table 2. Economic grievances and protest: Conditional models

\begin{tabular}{|c|c|c|c|c|}
\hline & Model 1 & Model 2 & Model 3 & Model 4 \\
\hline Relative status & $\begin{array}{l}-3.012^{* * *} \\
(0.197)\end{array}$ & & $\begin{array}{l}-3.087^{* * *} \\
(0.197)\end{array}$ & \\
\hline Deprivation & & $\begin{array}{l}2.110^{* * * *} \\
(0.516)\end{array}$ & & $\begin{array}{l}1.977^{* * *} \\
(0.588)\end{array}$ \\
\hline Mobilisation & $\begin{array}{l}-0.000^{*} \\
(0.000)\end{array}$ & $\begin{array}{l}-0.000 \\
(0.000)\end{array}$ & $\begin{array}{l}-0.000^{*} \\
(0.000)\end{array}$ & $\begin{array}{l}-0.000 \\
(0.000)\end{array}$ \\
\hline Relative status $\times$ Mobilisation & & & $\begin{array}{l}0.017^{* * *} \\
(0.004)\end{array}$ & \\
\hline Deprivation $\times$ Mobilisation & & & & $\begin{array}{c}0.025^{*} \\
(0.011)\end{array}$ \\
\hline Age & $\begin{array}{l}-0.004^{* * *} \\
(0.001)\end{array}$ & $\begin{array}{l}-0.003^{* * *} \\
(0.001)\end{array}$ & $\begin{array}{l}-0.004^{* * *} \\
(0.001)\end{array}$ & $\begin{array}{l}-0.003^{* * 3} \\
(0.001)\end{array}$ \\
\hline Female $(1=$ yes $)$ & $\begin{array}{l}0.143^{* * *} \\
(0.013)\end{array}$ & $\begin{array}{l}0.161^{* * *} \\
(0.013)\end{array}$ & $\begin{array}{l}0.141^{* * *} \\
(0.013)\end{array}$ & $\begin{array}{l}0.161^{* * *} \\
(0.013)\end{array}$ \\
\hline Education & $\begin{array}{l}0.253^{* 0 *} \\
(0.005)\end{array}$ & $\begin{array}{l}0.280^{\omega * * *} \\
(0.005)\end{array}$ & $\begin{array}{l}0.253^{*+* t} \\
(0.005)\end{array}$ & $\begin{array}{l}0.280^{* * *} \\
(0.005)\end{array}$ \\
\hline EmpStat.: education & $\begin{array}{l}0.581^{* * *} \\
(0.033)\end{array}$ & $\begin{array}{l}0.573^{* * *} \\
(0.033)\end{array}$ & $\begin{array}{l}0.581^{* * *} \\
(0.033)\end{array}$ & $\begin{array}{l}0.572^{* * *} \\
(0.033)\end{array}$ \\
\hline EmpStat.: unemployed & $\begin{array}{l}-0.013 \\
(0.029)\end{array}$ & $\begin{array}{c}-0.058^{*} \\
(0.029)\end{array}$ & $\begin{array}{c}-0.014 \\
(0.029)\end{array}$ & $\begin{array}{c}-0.058^{\circ} \\
(0.029)\end{array}$ \\
\hline EmpStat.: retired & $\begin{array}{l}-0.218^{* * *} \\
(0.023)\end{array}$ & $\begin{array}{l}-0.224^{* * *} \\
(0.023)\end{array}$ & $\begin{array}{l}-0.218^{* * *} \\
(0.023)\end{array}$ & $\begin{array}{l}-0.224^{* * *} \\
(0.023)\end{array}$ \\
\hline EmpStat.: housework & $\begin{array}{l}-0.076^{* *} \\
(0.026)\end{array}$ & $\begin{array}{l}-0.096^{*+*} \\
(0.026)\end{array}$ & $\begin{array}{l}-0.076^{6 *} \\
(0.026)\end{array}$ & $\begin{array}{l}-0.096^{* 04} \\
(0.026)\end{array}$ \\
\hline EmpStat.: other & $\begin{array}{r}0.149^{*} \\
(0.065)\end{array}$ & $\begin{array}{l}0.148^{*} \\
(0.065)\end{array}$ & $\begin{array}{r}0.149^{*} \\
(0.065)\end{array}$ & $\begin{array}{c}0.147^{*} \\
(0.065)\end{array}$ \\
\hline Partner $(1=$ yes $)$ & $\begin{array}{l}0.042^{* *} \\
(0.014)\end{array}$ & $\begin{array}{l}0.047^{* * *} \\
(0.014)\end{array}$ & $\begin{array}{l}0.042^{* *} \\
(0.014)\end{array}$ & $\begin{array}{l}0.047^{* * *} \\
(0.014)\end{array}$ \\
\hline Union member & $\begin{array}{l}0.310^{*+\infty} \\
(0.017)\end{array}$ & $\begin{array}{l}0.300^{* N * 0} \\
(0.017)\end{array}$ & $\begin{array}{l}0.310^{* * *} \\
(0.017)\end{array}$ & $\begin{array}{l}0.300^{*+n} \\
(0.017)\end{array}$ \\
\hline Other association member & $\begin{array}{l}1.279^{* * *} \\
(0.017)\end{array}$ & $\begin{array}{l}1.287^{* * *} \\
(0.018)\end{array}$ & $\begin{array}{l}1.279^{* * *} \\
(0.017)\end{array}$ & $\begin{array}{l}1.287^{6 *+4} \\
(0.018)\end{array}$ \\
\hline Unemployment rate & $\begin{array}{c}0.262 \\
(0.452)\end{array}$ & $\begin{array}{l}-0.022 \\
(0.435)\end{array}$ & $\begin{array}{c}0.283 \\
(0.450)\end{array}$ & $\begin{array}{c}-0.050 \\
(0.481)\end{array}$ \\
\hline Union density & $\begin{array}{c}0.004 \\
(0.005)\end{array}$ & $\begin{array}{c}0.004 \\
(0.005)\end{array}$ & $\begin{array}{c}0.004 \\
(0.005)\end{array}$ & $\begin{array}{c}0.004 \\
(0.005)\end{array}$ \\
\hline GovParty: Dom Right & $\begin{array}{c}-0.107^{* * *} \\
(0.029)\end{array}$ & $\begin{array}{l}-0.098^{* * *} \\
(0.029)\end{array}$ & $\begin{array}{c}-0.107^{* * * *} \\
(0.029)\end{array}$ & $\begin{array}{c}-0.101^{* * 8} \\
(0.029)\end{array}$ \\
\hline GovParty: Balance & $\begin{array}{l}-0.119^{* * * *} \\
(0.024)\end{array}$ & $\begin{array}{l}-0.108^{* * *} \\
(0.024)\end{array}$ & $\begin{array}{l}-0.118^{* * * *} \\
(0.024)\end{array}$ & $\begin{array}{l}-0.111^{* *+4} \\
(0.025)\end{array}$ \\
\hline
\end{tabular}


Table 2. Continued

\begin{tabular}{lcccc}
\hline & Model 1 & Model 2 & Model 3 & Model 4 \\
\hline GovParty: Dom Left & $-0.147^{*+* *}$ & $-0.145^{*+* *}$ & $-0.147^{* * *}$ & $-0.148^{* * * *}$ \\
& $(0.036)$ & $(0.036)$ & $(0.036)$ & $(0.036)$ \\
GovParty: Heg Left & $0.123^{* * *+*}$ & $0.125^{* * * *}$ & $0.122^{*+* * *}$ & $0.107^{*+*}$ \\
& $(0.036)$ & $(0.036)$ & $(0.036)$ & $(0.037)$ \\
AIC & 153704.344 & 150086.031 & 153686.126 & 150082.808 \\
Number of observations & 148,220 & 144,072 & 148,220 & 144,072 \\
Num. groups: cntry & 27 & 27 & 27 & 27 \\
Num. groups: year & 4 & 4 & 4 & 4 \\
Var: cntry (Intercept) & 0.561 & 0.540 & 0.562 & 0.542 \\
Var: year (Intercept) & 0.003 & 0.003 & 0.003 & 0.003 \\
\hline
\end{tabular}

Note: $* * * \mathrm{p}<0.001 ; * * \mathrm{p}<0.01 ; * \mathrm{p}<0.05$
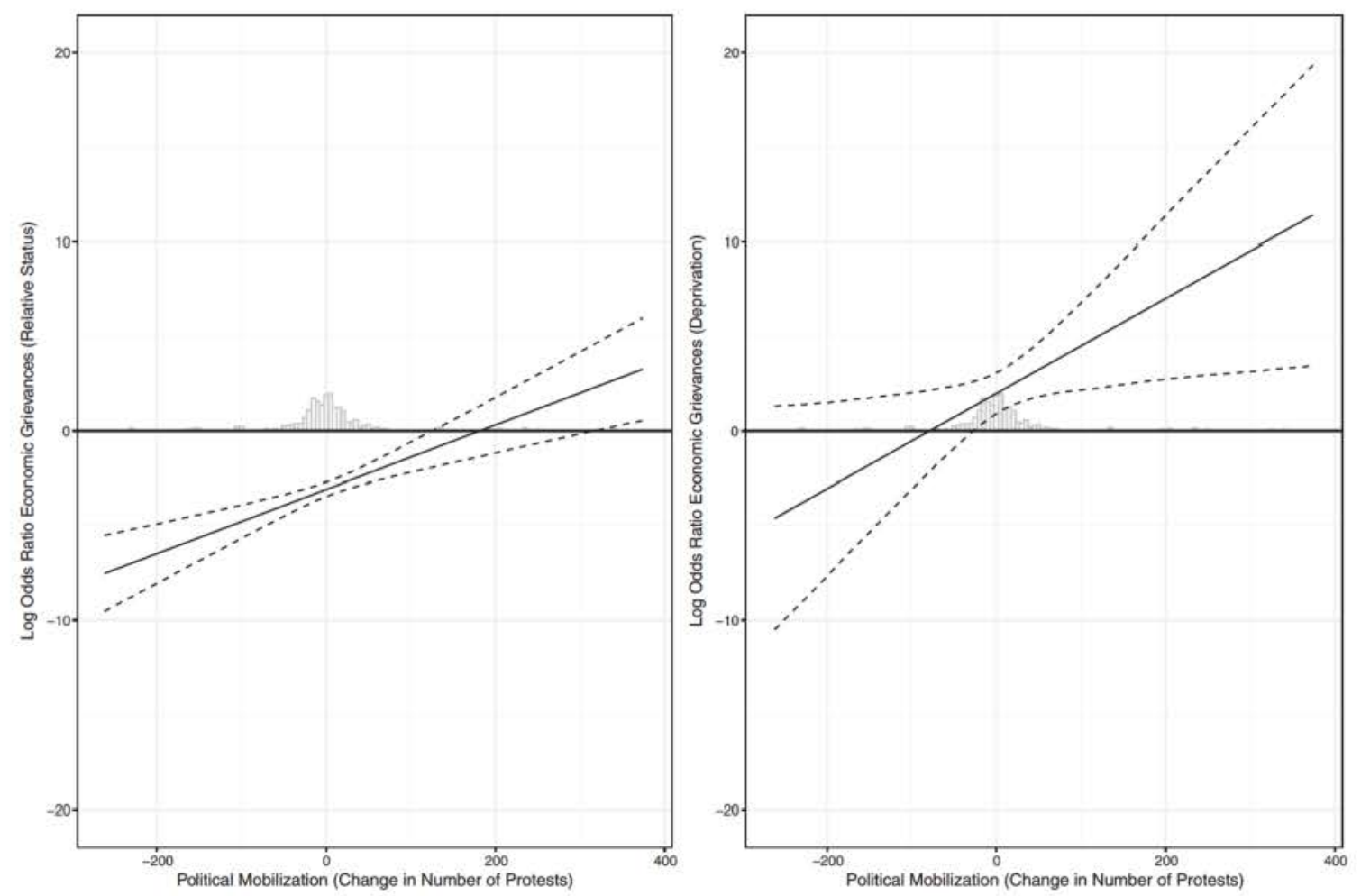

Figure 1. Economic grievances and protest: Conditional effects.

clearly reinforced in a mobilised protest context that offers ample opportunity to voice dissatisfaction and join existing protest movements.

The visualisation of the interaction effects in Figure 1 thus clearly adds credence to our hypothesis of a moderating role of mobilisation. A more vibrant political atmosphere activates disadvantaged citizens and either mitigates demobilising economic effects or reinforces mobilising effects. If there are visible opportunities to express dissatisfaction, citizens who face adverse economic conditions are much more likely to protest. In contrast, 


\begin{tabular}{lcccc}
\hline & $\begin{array}{c}\text { DV } \\
\text { cumulative }\end{array}$ & $\begin{array}{c}\text { DV w/o } \\
\text { boycott } \\
\text { products }\end{array}$ & $\begin{array}{c}\text { DV w/o } \\
\text { wearing badge }\end{array}$ & $\begin{array}{c}\text { Pre-crisis } \\
\text { sample }\end{array}$ \\
\hline Relative status & $-0.682^{* * * *}$ & $-2.802^{* * * *}$ & $-3.179^{* * *}$ & $-4.014^{* * *}$ \\
Mobilisation & $(0.058)$ & $>(0.210)$ & $(0.199)$ & $(0.387)$ \\
& $-0.000^{*}$ & $-0.000^{*}$ & $-0.000^{*}$ & $-0.000^{* *}$ \\
Relative status $\times$ Mobilisation & $(0.000)$ & $>(0.000)$ & $(0.000)$ & $(0.000)$ \\
& $0.003^{*}$ & $0.011^{* * *}$ & $0.017^{* * * *}$ & 0.006 \\
AIC & $(0.001)$ & $(0.004)$ & $(0.004)$ & $(0.005)$ \\
Number of observations & 336897.204 & 143368.309 & 151805.540 & 75332.566 \\
Num. groups: cntry & 148,220 & 148,220 & 148,220 & 71,936 \\
Num. groups: year & 27 & 27 & 27 & 25 \\
Var: cntry (Intercept) & 4 & 4 & 4 & 2 \\
Var: year (Intercept) & 0.063 & 0.458 & 0.623 & 0.471 \\
Var: Residual & 0.000 & 0.004 & 0.004 & 0.000 \\
\hline
\end{tabular}

Notes: ${ }^{* * *} \mathrm{p}<0.001 ;{ }^{* *} \mathrm{p}<0.01 ;{ }^{*} \mathrm{p}<0.05$. Covariates identical to Table 2 , not shown.

in case these grievances are not actively mobilised, economic deprivation might remain without consequences in the political arena. This is exactly what Kitschelt (1986) and other scholars have emphasised: economic grievances might be a driver of protest, but quite likely the degree of political engagement as a consequence of economic grievances depends on contextual factors that vary over time and space. Mobilisation and opportunity are key to activating the disadvantaged. Our findings are clearly in line with these claims.

\section{Robustness of results}

As a last step, we address several objections that might be raised to the presented results and demonstrate the robustness of our findings by running a number of additional analyses. First of all, we show that our findings do not hinge on the exact specification of the dependent variable. In our main model, we relied on a binary variable coded as 1 for all individuals that participated in one of four different forms of political protest the ESS asked for (demonstration, petition, wearing a badge and boycotting products). The dichotomisation of the variable based on four different items could be a source of bias. Model 1 in Tables 3 and 4 is thus based on a variable that ranges from 1 to 4 and measures cumulative protest activities of respondents. ${ }^{13}$ In addition, one might criticise the inclusion of both wearing a badge and taking part in product boycotts as measures of 'unconventional' participation or political protest in reaction to economic grievances. One the one hand, boycotting products, while clearly being unconventional, might not be seen as a very straightforward reaction to economic hardship. Accordingly, model 2 in Tables 3 and 4 demonstrates the robustness of our results to a narrow definition of our dependent variable that excludes boycotts. On the other hand, by the means of factor analysis, Kern et al. (2015) show that demonstrating, 
Table 4. Robustness: Deprivation

\begin{tabular}{lcccc}
\hline & $\begin{array}{c}\text { DV } \\
\text { cumulative }\end{array}$ & $\begin{array}{c}\text { DV w/o } \\
\text { boycott } \\
\text { products }\end{array}$ & $\begin{array}{c}\text { DV w/o } \\
\text { wearing badge }\end{array}$ & $\begin{array}{c}\text { Pre-crisis } \\
\text { sample }\end{array}$ \\
\hline Deprivation & $0.402^{*}$ & $1.448^{*}$ & $1.928^{* * * *}$ & $2.891^{* * *}$ \\
Mobilisation & $(0.162)$ & $(0.607)$ & $(0.549)$ & $(0.985)$ \\
Deprivation $\times$ Mobilisation & -0.000 & -0.000 & -0.000 & $-0.000^{* * *}$ \\
AIC & $(0.000)$ & $(0.000)$ & $(0.000)$ & $(0.000)$ \\
Number of observations & 0.006 & $0.031^{* * *}$ & $0.026^{*}$ & 0.026 \\
Num. groups: cntry & $(0.004)$ & $(0.012)$ & $(0.011)$ & $(0.016)$ \\
Num. groups: year & 328097.824 & 139927.671 & 148364.603 & 71709.215 \\
Var: cntry (Intercept) & 144,072 & 144,072 & 144,072 & 67,964 \\
Var: year (Intercept) & 27 & 27 & 27 & 23 \\
Var: Residual & 4 & 4 & 4 & 2 \\
\hline
\end{tabular}

Notes: ${ }^{* * *} \mathrm{p}<0.001 ;{ }^{* *} \mathrm{p}<0.01 ;{ }^{*} \mathrm{p}<0.05$. Covariates identical to Table 2 , not shown.

signing a petition and boycotting load on the same theoretical concept. As a consequence, they do not integrate the protest form of wearing a badge in their dependent variable. Model 3 in Tables 3 and 4 shows that our results are also robust to their operationalisation of protest.

The next robustness check is concerned with potential bias due to the extraordinary time span we analyse (i.e., the Great Recession). Our theoretical argument states a stable conditional relationship between economic grievances and protest. We would thus expect the core findings to be valid beyond the specific context of the Great Recession. What the financial crisis and the ensuing Great Recession essentially provide is a macroeconomic shock, resulting in a strong increase in the variance of our independent as well as our dependent variable. Increased variance on both sides of the equation therefore make the years between 2006 and 2012 an interesting test case for our hypothesis, which is not to claim that we would not find similar, but perhaps weaker, results in quiet times. As a consequence, model 4 is based on a reduced sample up to the year 2008 in order to demonstrate that our model does not take up a mere crisis effect and is valid more generally. The results, based on a much smaller sample size ( $\sim 70,000$ instead of $\sim 170,000)$, tend to support the general thrust of the hypothesis, but, as expected, the effects are weaker. Both coefficients are still positive but slightly smaller. The interaction effects are estimated imprecisely but closer inspection with the help of visualisations displaying the effect for the whole range of the moderator (as recommended by Brambor et al. 2006) confirms a positive and significant effect of deprivation for about 94 per cent of the entire pre-crisis sample (mobilisation levels of -30 and above).

Finally, one might be concerned that our results are driven by extreme values of our moderator variable, political mobilisation. Beyond the logged odds ratios, Figure 1 also displays the underlying distribution of this variable. One might object that our results are 
Table 5. Robustness: Trimmed sample

\begin{tabular}{lcccc}
\hline & Trim 1p & Trim 1p & Trim 5p & Trim 5p \\
\hline Relative status & $-3.044^{* * * * *}$ & & $-2.853^{* * * *}$ & \\
& $(0.198)$ & & $(0.213)$ & \\
Deprivation & & $1.876^{* * *}$ & & $2.074^{* * * *}$ \\
& & $(0.575)$ & & $(0.618)$ \\
Mobilisation & -0.000 & -0.000 & -0.001 & -0.000 \\
& $(0.000)$ & $(0.000)$ & $(0.000)$ & $(0.000)$ \\
Relative status $\times$ Mobilisation & $0.021^{* * *}$ & & $0.033^{* * *}$ & \\
& $(0.005)$ & & $(0.010)$ & \\
Deprivation $\times$ Mobilisation & & $0.046^{* *}$ & & $0.114^{* * * *}$ \\
& & $(0.016)$ & & $(0.028)$ \\
AIC & 146909.886 & 143294.598 & 126087.959 & 122397.211 \\
Number of observations & 142,478 & 138,330 & 124,041 & 119,893 \\
Num. groups: cntry & 27 & 27 & 27 & 27 \\
Num. groups: year & 4 & 4 & 4 & 4 \\
Var: cntry (Intercept) & 0.561 & 0.536 & 0.563 & 0.541 \\
Var: year (Intercept) & 0.003 & 0.003 & 0.003 & 0.002 \\
\hline
\end{tabular}

Notes: ${ }^{* * *} \mathrm{p}<0.001 ; * * \mathrm{p}<0.01 ;{ }^{*} \mathrm{p}<0.05$. Covariates identical to Table 2 , not shown.

driven by certain country-year observations with exceptionally high levels of change in the prevalence of protests. As a consequence, we run a sensitivity analysis and re-examined the conditional relationship between grievances and protest participation based on trimmed samples. We show that our results remain substantively unchanged when discarding both the 1 and 5 per cent lowest and highest values of our moderator variable (see Table 5 as well as A1 in the Appendix). The analysis based on the trimmed sample excludes, for example, all Greek respondents in 2008 - an exceptionally protest-intensive period around the outbreak of the financial crisis.

\section{Discussion and conclusion}

Are democratic principles fundamentally threatened in times of an increasingly unequal distribution of resources? The answer to this question depends on the extent to which economic disadvantage translates into political apathy. In this article, we aim to provide answers to this question by studying political protest in times of crisis. We combine insights from the political economy and social movement literature in order to gain a more comprehensive understanding of the relationship between economic grievances and political participation.

Clearly, economic ups and downs produce winners and losers, and if the latter increasingly turn their backs on politics, then the democratic ideal is at stake. Given the magnitude of these questions, the relationship between economic grievances and political participation has attracted much attention in political science, with the key question being whether economic hardship mobilises or de-mobilises adversely affected citizens. The 
existing studies have not yet produced an unequivocal answer to this question. In recent assessments of the relationship between economic hardship and individual political reaction, the so-called 'withdrawal hypothesis' (i.e., the pessimistic interpretation of the relationship between economic inequality and the quality of democracy) tends to prevail.

The first contribution of this article sheds light on the conceptual roots of the conflicting expectations between the mobilisation and withdrawal hypothesis. Based on traditional work dealing with social comparisons (e.g., Simon 1939), we offer a novel and innovative conceptualisation of economic grievances that highlights the importance of distinct reference groups. On the one hand, we examine the political consequences of economic grievances relative to other parts of society (relative status). On the other hand, we are interested in intertemporal changes: economic grievances relative to previous conditions (deprivation). We theoretically explain and empirically demonstrate that these two distinct concepts of economic grievances have very different behavioural implications. Relative status demobilises individuals, whereas deprivation over time has a mobilising effect. More careful conceptualisation of the explanatory variable, economic grievances, thus helps to considerably reduce ambiguity in the literature. The empirical measures we construct to capture these two types of grievances provide valuable middle ground between the two dominant approaches in existing literature, which either rely on absolute, rather blunt indicators of socioeconomic status or on entirely subjective perceptions of economic well-being. Since we explicitly take processes of social and intertemporal comparisons into account, our measures are closer to actually perceived hardship but at the same time circumvent endogeneity concerns related to survey items tapping into entirely subjective perceptions of economic conditions.

Our second contribution is based on a key message of the social movement literature that is often neglected in political economy approaches: political opportunity structures are crucial moderators between individual economic grievances and political reactions of affected workers. More precisely, political mobilisation and opportunity are crucial context conditions that influence the action repertoire of individuals and decisively affect the microlevel link between grievances and protest. We propose an innovative way of measuring political opportunity by means of original data on protest mobilisation during the Great Recession. Our results clearly show that a political environment that offers opportunity to voice dissatisfaction facilitates protest reactions among the disadvantaged. A vivid protest culture reinforces the mobilising effect of intertemporal deprivation and mitigates the demobilising effect of longstanding structural grievances (relative status). In exceptionally well-mobilised contexts, even relative status grievances entirely cease to depress political participation.

Our results imply that increasing economic inequality does not inevitably result in ever-increasing political inequality. While the danger of self-reinforcing economic and political inequality is certainly real, political actors within the democratic system have both the means and the power to break or at least mitigate this vicious circle. By providing opportunities to participate in the political process and to express dissatisfaction, political entrepreneurs, parties, trade unions, nongovernmental organisations and other forces within civil society can help reduce the demobilising effects of economic adversity and thereby mitigate participatory inequality. While there remains a large gap between the ideal and the reality of democracy, achieving more equal political voice is at least a first important 
step in opposing the detrimental influence of economic inequality on the functioning of contemporary democratic politics.

\section{Acknowledgments}

We would like to thank Johannes Lindvall, Jasmine Lorenzini, Daniel Bischof, Tabea Palmtag participants of the 23rd International Conference of Europeanists in Philadelphia, workshop participants at the University of Zurich as well as three anonymous reviewers for many helpful comments. We are also grateful to the editors of the EJPR for their support during the review process.

\section{Appendix}

Table A1. Total number of protest events, by type

\begin{tabular}{lcccccc}
\hline Year & Strikes & Petitions & Demonstrations & Blockades & Violent protests & Other \\
\hline 2005 & 362 & 196 & 733 & 114 & 568 & 51 \\
2006 & 338 & 147 & 753 & 132 & 384 & 53 \\
2007 & 404 & 203 & 769 & 160 & 453 & 56 \\
2008 & 484 & 263 & 885 & 240 & 538 & 80 \\
2009 & 288 & 188 & 956 & 197 & 498 & 70 \\
2010 & 476 & 147 & 907 & 155 & 434 & 57 \\
2011 & 340 & 168 & 954 & 196 & 394 & 58 \\
2012 & 358 & 197 & 985 & 115 & 322 & 72 \\
2013 & 254 & 151 & 820 & 113 & 330 & 70 \\
2014 & 236 & 116 & 631 & 74 & 211 & 34 \\
Total & 3,540 & 1,776 & 8,393 & 1,496 & 4,132 & 601 \\
\hline
\end{tabular}

Table A2. Descriptive statistics: Micro-level data

\begin{tabular}{lccccc}
\hline & Mean & Standard deviation & Median & Minimum & Maximum \\
\hline Protest (ind.) & 0.316 & 0.465 & 0 & 0 & 1 \\
Female & 0.538 & 0.499 & 1 & 0 & 1 \\
Education & 3.089 & 1.346 & 3.00 & 0 & 5.00 \\
Age & 48.263 & 18.574 & 48.00 & 14.00 & 123.00 \\
Partner & 0.574 & 0.494 & 1 & 0 & 1 \\
Union membership & 0.178 & 0.382 & 0 & 0 & 1 \\
Other association member & 0.141 & 0.348 & 0 & 0 & 1 \\
Relative status & -01 & 0.038 & -0 & -0.14 & 0.16 \\
Deprivation & 02 & 0.016 & 0 & -0.14 & 0.19 \\
Mobilisation & 1.457 & 59.947 & -1 & -262.00 & 374.00 \\
Unemployment rate & 0.064 & 0.040 & 0.06 & 0 & 0.21 \\
Union density & 29.207 & 19.751 & 20.49 & 6.53 & 91.54 \\
\hline
\end{tabular}



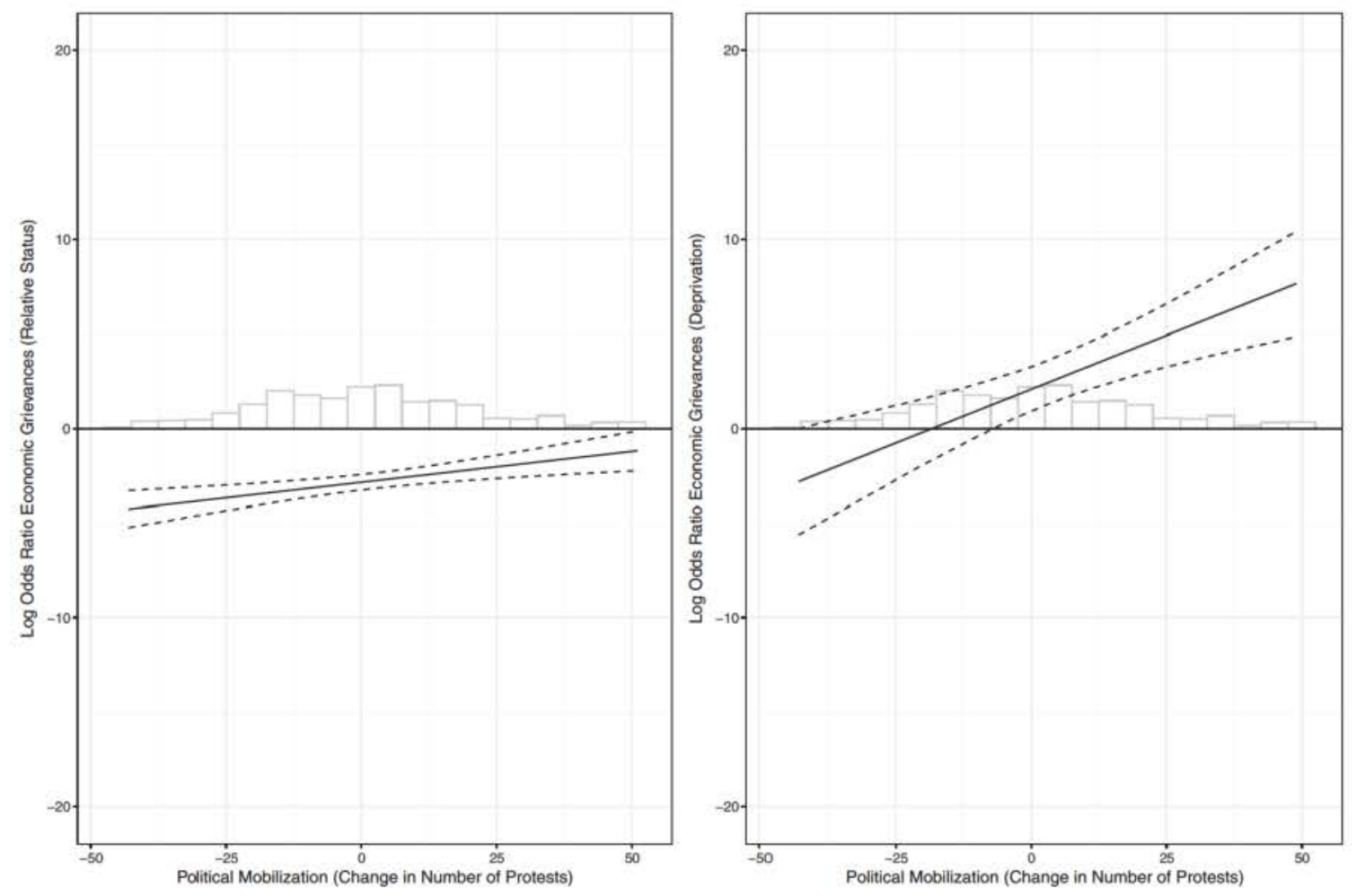

Figure A1. Economic grievances and protest: Conditional effects (trimmed sample).

\section{Online Appendix}

Additional supporting information may be found online in the Online Appendix at the end of the article:

\section{Additional descriptive statistics}

Table SI1: Yearly evolution of class- and country-specic unemployment risk and re- sulting values for both measures of economic grievances, relative status and deprivation. Example: Spain 2004.

Table SI2: Yearly minima, mean and maxima of both measures of economic grievances, relative status and deprivation, for each country.

Table SI3: Descriptive statistics of micro-level variables per country.

Table SI4-SI7: Descriptive statistics of micro-level variables per country, separate for each year.

\section{Additional empirical analyses}

Table SI8: Two-way xed-e ects models instead of the multilevel specication pre- sented in the article.

\section{Objective vs. subjective grievances}

Table SI9: Our grievance measures, relative status and deprivation, regressed on di erent ESS items intended to capture subjectively perceived hardship/dissatisfaction (standardized and non-standardized coe cients). 


\section{Notes}

1. In some sense, the distinct behavioural implications we expect are related to Kerbo's (1982) distinction between movements of affluence and movements of crisis. The first are sustained by individuals whose basic needs are met, which is why they have resources to devote to social movements, while the latter are motivated by 'beneficiary members' who protest worsening individual conditions.

2. In the section on robustness, we demonstrate that our results do not hinge on this specific operationalisation. We also coded an alternative count version of the dependent variable ranging from zero to four and two binary versions that exclude wearing a badge and boycotts, respectively, means of participation that might be considered less straightforward reactions to economic hardship. All the results shown below are robust to these alternative specifications.

3. We rely on Oesch's (2006) class scheme with the following eight occupational groups: large employers and liberal (self-employed) professionals; technical (semi-) professions; (associate) managers in business and public sector; sociocultural (semi-) professions; petit bourgeoisie and small business owners; production workers; office clerks; and service workers. This differs from Schwander and Häusermann (2013) who are particularly interested in 'outsiderness' and thus further subdivide their baseline occupational class groups along the sociodemographic characteristics of gender and age, which are strongly related to being an outsider. In our case, we look at unemployment rates and here the relation to gender and age is less straightforward, which is why we do not further divide our baseline groups of occupational classes. The resulting measure is thus very close the one developed by Rehm (2009) who looked at unemployment rates within occupational groups defined by ISCO codes.

4. Quantitative content analyses of media data in general and the method of protest event analysis (PEA) in particular has a longstanding tradition in research on social movements (Hutter 2014: xvii). Despite - or exactly because of - its popularity, it has attracted criticism. Three potential methodological downsides have been emphasised in particular: the choice of the data selection scheme, selection bias and description bias (see Earl et al. 2004). The first is not considered problematic, as we rely on an encompassing semi-automated collection of news wires without a pre-defined sampling strategy. In addition, since we only rely on 'hard news' - that is, date and place of a protest event - the veracity of the reporting related to description bias is considered unproblematic as well. Selection bias, finally, surely exists to some extent (Hutter 2014: 147). However, a systematic comparison of our own media data with two alternative datasets, one quantitative and one qualitative, comes to the conclusion that our data-generation process 'does not bias the data in important ways' (Wüest \& Lorenzini 2017: 18).

5. To be precise, we add up protests that took place in the 12 months preceding the month in which the respondent's interview took place. This individually adjusted values for the moderator variable seems necessary as ESS fieldwork often continues over several months and varies considerably between countries. Exceptions to this procedure are the ESS waves of Austria 2008, Austria 2010 and Estonia 2008 for which the date of the interview was not available. Here, we instead relied on the country-yearspecific midpoint of the ESS fieldwork.

6. As a positive side effect, we would expect that studying changes in instead of absolute numbers of protest reduces potential problems of selection if some regions are less-well covered by our sources.

7. Furthermore, it is important to clarify that in our framework, mobilisation is not the main explanatory variable but moderating the micro-level relationship between economic grievances and participation in protests. Even if a change in the number of protest was correlated with our dependent variable, this would not imply that we also find differential effects on winners and losers of economic hardship - that is, the interaction effect we propose in our hypothesis.

8. AT, BE, BG, CH, CY, CZ, DE, DK, EE, ES, FI, FR, GR, HU, IE, IS, IT, LT, LV, NL, NO, PL, PT, RO, SE, SI, SK, UK.

9. We rely on logistic regression because due to the different forms of protest combined in our dependent variable, the distribution is clearly less unbalanced than usually when examining, for example, participation in demonstrations. Therefore, we did not run models accounting for zero inflation or heavy skew. In addition, robustness to a fixed-effects specification is demonstrated in the Online Appendix. 
10. Note that such problems are not endemic to Schmidt-Catran and Fairbrother's (2016) recommendation; they simply arise in the current application.

11. These findings are generally valid and not driven by the economic consequences of the financial crisis. In the section on robustness, we provide the estimates of regressions based on a sample limited to pre-crisis years.

12. Figure 1 is based on the entire in-sample variance of political mobilisation. A1 in the Appendix (discussed below) shows conditional effects based on a trimmed sample excluding extreme values.

13. For the sake of simplicity, we opted for a linear rather than an ordered logit or count regression model.

\section{References}

Alderson, A.S. \& Nielsen, F. (2002). Globalization and the great U-turn: Income inequality trends in 16 OECD countries. American Journal of Sociology 107(5): 1244-1299.

Arzheimer, K. (2009). Contextual factors and the extreme right vote in Western Europe, 1980-2002. American Journal of Political Science 53(2): 259-275.

Barnes, S.H., Farah, B.G. \& Heunks, F. (1979). Personal dissatisfaction. In S.H. Barnes \& M. Kaase (eds), Political action: Mass participation in five Western democracies. Beverly Hills, CA: Sage.

Bartels, L.M. (2008). Unequal democracy: The political economy of the new gilded age. Princeton, NJ: Princeton University Press.

Bernburg, J.G. (2015). Economic crisis and popular protest in Iceland, January 2009: The role of perceived economic loss and political attitudes in protest participation and support. Mobilization 20(2): 231-252.

Blais, A. \& Dobrzynska, A. (1998). Turnout in electoral democracies. European Journal of Political Research 33(2):239-261.

Brady,H.E. (2004). An analytical perspective on participatory inequality and income inequality. In Kathryn M. Neckerman (ed.), Social Inequality. New York: Russell Sage Foundation.

Brady, H.E., Verba, S. \& Schlozman, K.L. (1995). Beyond SES: A resource model of political participation. American Political Science Review 89(2): 271-294.

Brambor, T., Clark, W.R. \& Golder, M. (2006). Understanding interaction models: Improving empirical analyses. Political Analysis 14(1): 63-82.

Braun, R. \& Koopmans, R. (2009). The diffusion of ethnic violence in Germany: The role of social similarity. European Sociological Review 26(1): 111-123.

Cederman, L.-E., Weidmann, N.B. \& Gleditsch, K.S. (2011). Horizontal inequalities and ethnonationalist civil war: A global comparison. American Political Science Review 105(3): 478-495.

Dahl, R.A. (1998). On democracy. New Haven, CT: Yale University Press.

Della Porta, D. (2008). Research on social movements and political violence. Qualitative Sociology 31(3): 221-230.

Della Porta, D. (2014). Mobilizing for democracy: Comparing 1989 and 2011. Oxford: Oxford University Press.

Della Porta, D. (2015). Social movements in times of austerity: Bringing capitalism back into protest analysis. Cambaridge: Polity Press.

Earl, J., Martin, A., McCarthy, J.D. \& Soule, S.A. (2004). The use of newspaper data in the study of collective action. Annual Review of Sociology 30(1): 65-80.

Eisinger, P.K. (1973). The conditions of protest behavior in American cities. American Political Science Review 67(1): 11-28.

Emmenegger, P., Häusermann, S., Palier, B. \& Seeleib-Kaiser, M. (eds) (2012). The age of dualization: The changing face of inequality in deindustrializing societies. Oxford: Oxford University Press.

Galais, C. \& Lorenzini, J. (2017). Half a loaf is (not) better than none: How austerity-related grievances and emotions triggered protests in Spain. Mobilization 22(1): 77-95.

Geschwender, J.A. (1964). Social Structure and the Negro revolt: An examination of some hypotheses. Social Forces 43(2): 248-256. 
Giugni, M. \& Grasso, M.T. (2015). Austerity and protest: Popular contention in times of economic crisis. Farnham: Ashgate.

Granovetter, M. (1978). Threshold models of collective behavior. American Journal of Sociology 83:489-515.

Grasso, M.T. \& Giugni, M. (2016). Protest participation and economic crisis: The conditioning role of political opportunities. European Journal of Political Research 55(4): 663-680.

Griffin, J.D. \& Newman, B. (2005). Are voters better represented? Journal of Politics 67(4): 1206-1227.

Gurney, J.N. \& Tierney, K.J. (1982). Relative deprivation and social movements: A critical look at twenty years of theory and research. Sociological Quarterly 23(1):33-47.

Gurr, T.R. (1970). Why men rebel. Princeton, NJ: Princeton University Press.

Hacker, J.S., Rehm, P. \& Schlesinger, M. (2013). The insecure American: Economic experiences, financial worries and policy attitudes. Perspectives on Politics 11(1):23-49.

Harrison, B. \& Bluestone, B. (1988). The great U-turn: Corporate restructuring and the polarizing of America. New York: Basic Books.

Häusermann, S., Kurer, T. \& Schwander, H. (2015). High-skilled outsiders? Labor market vulnerability, education and welfare state preferences. Socio-Economic Review 13(2): 235-258.

Häusermann, S., Kurer, T. \& Wüest, B. (2018). Participation in hard times: How constrained government depresses turnout among the highly educated. West European Politics 41(2): 448-471.

Hetland, G. \& Goodwin, J. (2013). The strange disappearance of capitalism from social movement studies. Marxism and Social Movements 46: 86-98.

Hutter, S. (2014). Protesting culture and economics in Western Europe: New cleavages in left and right politics. Minneapolis, MN: University of Minnesota Press.

Incantalupo, M.B. (2011). The effects of unemployment on voter turnout in US national elections. Unpublished manuscript.

Kerbo, H.R. (1982). Movements of 'crisis' and movements of 'affluence': A critique of deprivation and resource mobilization theories. Journal of Conflict Resolution 26(4): 645-663.

Kern, A., Marien, S. \& Hooghe, M. (2015). Economic crisis and levels of political participation in Europe (2002-2010): The role of resources and grievances. West European Politics 38(3): 465-490.

Kitschelt, H.P. (1986). Political opportunity structures and political protest: Anti-nuclear movements in four democracies. British Journal of Political Science 16(1):57-85.

Koopmans, R. (1999). Political. Opportunity. Structure: Some splitting to balance the lumping. Sociological Forum 14(1): 93-105.

Kriesi, H. (1989). The political opportunity structure of the Dutch peace movement. West European Politics 12(3): 295-312.

Kriesi, H. (2004). Political context and opportunity. In D. Snow, S. Soule \& H. Kriesi (eds), The Blackwell companion to social movements. Abingdon: John Wiley \& Sons.

Kriesi, H. (2014). The political consequences of the economic crisis in Europe: Electoral punishment and popular protest. In N. Bermeo \& L.M. Bartels (eds), Mass politics in tough times: Opinions, votes and protest in the Great Recession. Oxford: Oxford University Press.

Kriesi, H., Koopmans, R., Duyvendak, J.W. \& Giugni, M.G. (1992). New social movements and political opportunities in Western Europe. European Journal of Political Research 22(2):219-244.

Kriesi, H., Koopmans, R., Duyvendak, J.W. \& Giugni, M.G. (1995). New social movements in Western Europe: A comparative analysis. Minneapolis, MN: University of Minnesota Press.

Kuran, T. (1991). Now out of never: The element of surprise in the East European revolution of 1989. World Politics 44(1): 7-48.

Lohman, S. (1994). The dynamics of informational cascades: The Monday demonstrations in Leipzig, East Germany, 1989-91. World Politics 47(1): 42-101.

Lorenzini, J., Makarov, P. \& Wüest, B. (2016). Towards a dataset of automatically coded protest events from English-language newswires. Unpublished manuscript.

Mair, P. (2006). Ruling the void: The hollowing of Western democracy. New Left Review 42: 25-51.

Mair, P. (2013). Smaghi versus the parties: Representative government and institutional constraints. In W. Streeck \& A. Schäfer (eds), Politics in the age of austerity. Cambridge: Polity. 
McCammon, H.J., Muse, C.S., Newman, H.D. \& Terrell, T.M. (2007). Movement framing and discursive opportunity structures: The political successes of the US women's jury movements. American Sociological Review 72(5): 725-749.

Milbrath, L.W. \& Goel, M L. (1977). Political participation: How and why do people get involved in politics? Chicago, IL: Rand McNally.

Oesch, D. (2006). Redrawing the class map: Stratification and institutions in Britain, Germany, Sweden and Switzerland. Basingstoke: Palgrave Macmillan.

Offe, C. (2013). Participatory inequality in the austerity state: A supply-side approach. In W. Streeck \& A. Schäfer (eds), Politics in the age of austerity. Cambridge: Polity.

Oliver, J.E. (2001). Democracy in surburbia. Princeton, NJ: Princeton University Press.

Organisation for Economic Cooperation and Development (OECD) (2008). Growing unequal? Paris: OECD.

Organisation for Economic Cooperation and Development (OECD) (2011). Divided we stand. Paris: OECD.

Ostby, G. (2008). Polarization, horizontal inequalities and violent civil conflict. Journal of Peace Research 45(2): 143-162.

Pettigrew, T.F. (2016). In pursuit of three theories: Authoritarianism, relative deprivation and intergroup contact. Annual Review of Psychology 67(1): 1-21.

Piketty, T. (2014). Capital in the twenty-first century. Cambridge, MA: Belknap Press.

Rehm, P. (2009). Risks and redistribution An individual-level analysis. Comparative Political Studies 42(7): $855-881$.

Rehm, P. (2011). Social policy by popular demand. World Politics 63(2):271-299.

Rehm, P.(2016). Risk inequality and welfare states: Social policy preferences, development and dynamics. New York: Cambridge University Press.

Rehm, P., Hacker, J.S. \& Schlesinger, M. (2012). Insecure alliances: Risk, inequality and support for the welfare state. American Political Science Review 106(2): 386-406.

Rosenstone, S.J. (1982). Economic adversity and voter turnout. American Journal of Political Science 26(1): 25-46.

Rovny, J. \& Rovny, A. (2017). Outsiders at the ballot box: Operationalizations and political consequences of the insider-outsider dualism. Socio-Economic Review 15(1): 161-185.

Rüdig, W. \& Karyotis, G. (2014). Who protests in Greece? Mass opposition to austerity. British Journal of Political Science 44(3): 487-513.

Runciman, W.G. (1966). Relative deprivation and social justice. Berkeley, CA: University of Califorina Press.

Schlozman, K.L. \& Verba, S. (1979). Injury to insult: Unemployment, class and political response. Cambridge, MA: Harvard University Press.

Schmidt-Catran, A.W. \& Fairbrother, M. (2016). The random effects in multilevel models: Getting them wrong and getting them right. European Sociological Review 32(1): 23-38.

Schwander,H.\& Häusermann,S. (2013). Who is in and who is out? A risk-based conceptualization of insiders and outsiders. Journal of European Social Policy 23(3): 248-269.

Simon, H.A. (1939). The administrator in search of statistics. Public Management 21:106-109.

Smeeding, T.M. (2005). Public policy, economic inequality and poverty: The United States in comparative perspective. Social Science Quarterly 86(s1): 955-983.

Solt, F. (2008). Economic inequality and democratic political engagement. American Journal of Political Science 52(1): 48-60.

Solt, F. (2015). Economic inequality and nonviolent protest. Social Science Quarterly 96(5): 1314-1327.

Stanley, J. \& Goodwin, J. (2013). Political economy and social movements. In D. Snow, D. Della Porta, B. Klandermans \& D. McAdam (eds), The Wiley-Blackwell encyclopedia of social and political movements. Oxford: Blackwell.

Streeck, W. \& Schäfer, A. (2013). Politics in the age of austerity. Cambridge: Polity.

Tarrow, S. (1994). Power in movement: Social movements, collective action and politics. Cambridge: Cambridge University Press.

Verba, S. \& Nie, N.H. (1972). Participation in America: Political democracy and social equality. New York: Harper \& Row. 
Verba, S., Schlozman, K.L. \& Brady, H.E. (1995). Voice and equality: Civic voluntarism in American politics. Cambridge, MA: Harvard University Press.

Wolfinger, R.E. \& Rosenstone, S.J. (1980). Who votes? New Haven, CT: Yale University Press.

Wüest, B. \& Lorenzini, J. (2017). External validation of the protest event analysis. Unpublished manuscript.

Address for correspondence: Thomas Kurer, Weatherhead Center for International Affairs, Harvard University, 1737 Cambridge St, Cambridge, MA 02138, USA. Email: tkurer@wcfia.harvard.edu 